\title{
Dysregulation of Amyloid- $\beta$ Protein Precursor, $\beta$-Secretase, Presenilin 1 and 2 Genes in the Rat Selectively Vulnerable CA1 Subfield of Hippocampus Following Transient Global Brain Ischemia
}

\author{
Janusz Kocki ${ }^{\mathrm{a}, 1}$, Marzena Ułamek-Kozioł ${ }^{\mathrm{b}, 1}$, Anna Bogucka-Kockac ${ }^{\mathrm{c}}$, Sławomir Januszewski ${ }^{\mathrm{b}}$,

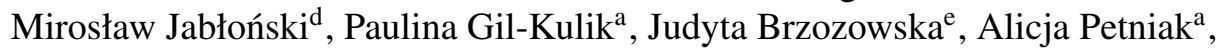 \\ Wanda Furmaga-Jabłońska ${ }^{\mathrm{f}}$, Jacek Bogucki ${ }^{\mathrm{g}}$, Stanisław J. Czuczwar ${ }^{\text {h,i }}$ and Ryszard Pluta ${ }^{\mathrm{b}, *}$ \\ ${ }^{a}$ Department of Clinical Genetics, Medical University of Lublin, Lublin, Poland \\ ${ }^{\mathrm{b}}$ Laboratory of Ischemic and Neurodegenerative Brain Research, Mossakowski Medical Research Centre, \\ Polish Academy of Sciences, Warsaw, Poland \\ ${ }^{\mathrm{c}}$ Department of Pharmaceutical Botany, Medical University of Lublin, Lublin, Poland \\ ${ }^{\mathrm{d}}$ Department of Rehabilitation and Orthopaedics, Medical University of Lublin, Lublin, Poland \\ ${ }^{\mathrm{e}}$ Department of Clinical Psychology, Medical University of Lublin, Lublin, Poland \\ ${ }^{\mathrm{f}}$ Department of Neonate and Infant Pathology, Medical University of Lublin, Lublin, Poland \\ ${ }^{\mathrm{g}}$ Warsaw Higher Humanistic School, Warsaw, Poland \\ ${ }^{\mathrm{h}}$ Department of Pathophysiology, Medical University of Lublin, Lublin, Poland \\ ${ }^{\mathrm{i}}$ Department of Physiopathology, Institute of Rural Medicine, Lublin, Poland
}

\begin{abstract}
The interaction between brain ischemia and Alzheimer's disease (AD) has been intensively investigated recently. Nevertheless, we have not yet understood the nature and mechanisms of the ischemic episodes triggering the onset of AD and how they influence its slow progression. The assumed connection between brain ischemia and the accumulation of amyloid- $\beta$ $(\mathrm{A} \beta)$ peptide awaits to be clearly explained. In our research, we employed a rat cardiac arrest model to study the changes in gene expression of amyloid- $\beta$ protein precursor (A $\beta \mathrm{PP}$ ) and its cleaving enzymes, $\beta$ - and $\gamma$-secretases (including presenilins) in hippocampal CA1 sector, following transient 10-min global brain ischemia. The quantitative reverse-transcriptase PCR assay demonstrated that the expression of all above genes that contribute to $A \beta$ peptide generation was dysregulated during 30 days in postischemic hippocampal CA1 area. It suggests that studied A $\beta$ peptide generation-related genes can be involved in A $\beta$ PP metabolism, following global brain ischemia and will be useful to identify the molecular mechanisms underpinning
\end{abstract}

\footnotetext{
${ }^{1}$ These authors contributed equally to this work.

*Correspondence to: Prof. Ryszard Pluta, MD, PhD, Laboratory of Ischemic and Neurodegenerative Brain Research, Mossakowski
}

Medical Research Centre, Polish Academy of Sciences, 02-106 Warsaw, Pawińskiego 5 Str., Poland. Tel.: +48 226086 540/60 86 469; Fax: +48 2266855 32; E-mail: pluta@imdik.pan.pl. 
that cerebral ischemia might be an etiological cause of $\mathrm{AD}$ via dysregulation of $\mathrm{A} \beta \mathrm{PP}$ and its cleaving enzymes, $\beta$ - and $\gamma$ secretases genes, and subsequently, it may increase $A \beta$ peptide production and promote the gradual and slow development of AD neuropathology. Our data demonstrate that brain ischemia activates delayed neuronal death in hippocampus in an

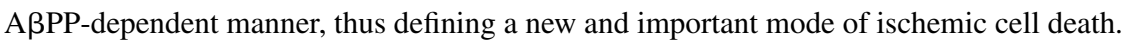

Keywords: Alzheimer's disease, amyloid- $\beta$ protein precursor, $\beta$-secretase, brain ischemia, CA1 area, dementia, $\gamma$-secretase, genes, hippocampus, presenilin 1 and 2

\section{INTRODUCTION}

Transient global brain ischemia and Alzheimer's disease (AD) are two familiar neurodegenerative disorders, which at first cause progressive degeneration in rodents as well as in humans, followed by death of hippocampal populations of pyramidal neurons in the CA1 area, with the final development of dementia [1-11]. Ischemic brain injury is the second cause of dementia, the third leading cause of death in the world, and a major cause of progressing adult disability worldwide, for which there is no effective therapy so far [12]. Transient global ischemia in rodents and humans induces a continuous loss of hippocampal pyramidal neurons, beginning $48 \mathrm{~h}$ after the end of ischemia [13-16]. This form of neuronal loss is termed selective delayed neuronal death or the "maturation phenomenon" [13-16]. Selective delayed neuronal death of CA1 field of hippocampus is intensively studied in rodents, and it is the most sensitive area of the brain to ischemic damage [9]. A phenomenon of specific delayed neuronal death in ischemic hippocampus is defined, however, the molecular chain of events ending in death of CA1 area pyramidal neuronal population is not stated precisely.

$\mathrm{AD}$, the leading source of dementia worldwide, is defined neuropathologically by the loss of CA1 area neurons in hippocampus and presence of the soluble and fibrillar amyloid- $\beta(\mathrm{A} \beta)$ peptide within the brain intra- and extracellular space along with hyperphosphorylated tau protein inside neurons $[10,11]$. In addition to $\mathrm{AD}, \mathrm{A} \beta$ peptide and hyperphosphorylated tau protein are noted to be powerfully involved in the development of neurodegeneration following transient global brain ischemia in humans and animals [16-22]. Brain ischemia may trigger initiating processes in the cascade of neuropathogenesis in AD onset, progression, and development finishing with full-blown cognitive deficits with Alzheimer phenotype [6-8, 23, 24]. Complete brain ischemia induces delayed neuronal death characterized by massive neuronal loss in hippocampal CA1 subfield, which starts during the 2nd day and finishes during the 7 th day of recirculation [13-16].
Ischemic delayed neuronal loss in animals and humans is associated with spatial memory deficits and hyperactivity, and these alterations directly correlate with ischemia-induced hippocampal CA1 area cell death [4, $8,25]$, hippocampal and brain atrophy [26], and finally result in severe dementia [8,24].

It has been demonstrated that increased levels of different fragments of amyloid- $\beta$ protein precursor (A $\beta P P)$ immunoreactivity in hippocampus, starting 2 days following global brain ischemia in rat, are still present within one year [17, 26-31]. Additionally, $A \beta$ peptide deposition was also detected in the human hippocampus following complete brain ischemia $[18,32]$. In rat and human ischemic brains, different fragments of A $\beta P P$ have been found, especially in neuronal cells [16-18, 32, 33]. The above data indicate that an ischemic episode induces pathological A $\beta P P$ metabolism in ischemic neurons. After the transient global brain ischemia, recirculation affects $\mathrm{A} \beta \mathrm{PP}$ processing, finally ending in the rise of $A \beta$ peptide accumulation in the intra- and extracellular space of brain. $\mathrm{A} \beta$ peptide plaques in $\mathrm{AD}$ are produced from $\mathrm{A} \beta \mathrm{PP}$ in a rapid and highly complex process via proteolytic cleavage by $\beta$-secretase and $\gamma$ secretase complex (including presenilins). $\gamma$-Secretase can cleave $\mathrm{A} \beta \mathrm{PP}$ at several neighboring intramembranous sites to release $A \beta$ peptide, a hydrophobic self-aggregating peptide, containing 39-42 amino acid residues.

Here we investigated whether A $\beta P P$ signaling pathway participates in ischemia-induced delayed neuronal death in CA1 area of hippocampus. In this study, we have presented for the first time the time course of A $\beta P P, \beta$-secretase and presenilin 1 and 2 gene dysregulation by quantitative reverse-transcriptase PCR assay protocol, all of which are implicated in $\mathrm{AD}$, in the selectively vulnerable CA1 sector of rat hippocampus subjected to transient global brain ischemia due to cardiac arrest with survival times of 2, 7, and 30 days. Our data demonstrate that brain ischemia activates delayed neuronal death in hippocampus in an A $\beta P P-d e p e n d e n t$ manner, thus defining a new and important mode of ischemic cell death. 


\section{MATERIALS AND METHODS}

\section{Animals and global brain ischemia}

Two-month-old female Wistar rats $(n=54$, 160-180 g) were submitted to 10-min global brain ischemia due to cardiac arrest [34]. The rats were maintained in pairs per cage in a room temperature of $24 \pm 2^{\circ} \mathrm{C}$, with $55 \pm 5 \%$ humidity, and with a 12-h light-dark cycle. All animals had free access to commercial laboratory chow and tap water ad libitum. All experimental procedures were performed during the light phase, between 13:00 and 17:00 under identical conditions. The rats used for experiments were treated in strict accordance with the NIH Guide for Care and Use of Laboratory Animals (1985) and European Communities Council Directive 142 (86/609/EEC), as well as with the approval of the local Ethical Committee. All efforts were made to minimize animal suffering and to reduce the number of rats used.

Our animal model of global brain ischemia in rats clinically represents reversible cardiac arrest. Global brain ischemia was performed by cardiac arrest of 10-min duration [34]. The animals were allowed to survive $2(n=11), 7(n=18)$ days, and 1 month $(n=25)$ after recirculation. Sham-operated rats $(n=54)$ were exposed to the same procedures as ischemic animals but without induced cardiac arrest and thus served as controls.

\section{Determination of gene expression}

Prior to sampling, the brains were perfused with cold $0.9 \% \mathrm{NaCl}$ via the left ventricle in order to flush blood vessels. After removing the brain from the skull, the brain was put on an ice chilled Petri dish. The brains were cut in the coronal plane through the intersection of the optic nerves. The ischemic and control pooled samples circa $1 \mathrm{~mm}^{3}$ volume of hippocampal left and right CA1 area were taken with a narrow scalpel. Pooled left and right CA1 areas were immediately placed in RNALater solution (Life Technologies, USA). Gene expression of amyloid- $\beta$ protein precursor (App), $\beta$-secretase (Bace 1), presenlin 1 (Psen 1), and presenilin 2 (Psen 2) was assessed by reverse-transcription quantitative PCR (RT-qPCR) method. Genes were quantitatively assessed in each sample taken from the ischemic group and referred to gene expression determined in the corresponding samples in the control group - 1:1.

\section{Isolation of total cellular RNA}

Total cellular RNA isolation was performed according to the method described by Chomczynski and Sacchi [35] with modification, using TRI-Reagent Solution (Ambion, USA). During this process, the samples of hippocampal CA1 area were homogenized in $1 \mathrm{ml}$ TRI-Reagent buffer (Ambion, USA) to obtain homogenous suspension. The suspensions were incubated for $5 \mathrm{~min}$ at room temperature until complete dissociation. At the next stage, $200 \mu \mathrm{l}$ chloroform (Sigma-Aldrich, USA) per $1 \mathrm{ml}$ of TRI-Reagent buffer was added to the sample and shaken for $15 \mathrm{~s}$ to completely mix the phases. Next, the samples were left for $15 \mathrm{~min}$ to incubate at room temperature after which they were centrifuged for $15 \mathrm{~min}$ at $14,000 \mathrm{rpm}$ at $4{ }^{\circ} \mathrm{C}$ in $5415 \mathrm{R}$ Eppendorf centrifuges. After the separation, the aqueous phase was placed in a new tube and $500 \mu \mathrm{l}$ 2-propanol (Sigma-Aldrich, USA) was added per $1 \mathrm{ml}$ of TRI-Reagent buffer. The samples were thoroughly mixed and incubated for $20 \mathrm{~min}$ at room temperature. Following that, the mixtures were centrifuged for $20 \mathrm{~min}$ at $14,000 \mathrm{rpm}$ at $4^{\circ} \mathrm{C}$ in $5415 \mathrm{R}$ Eppendorf centrifuges. Aqueous phase containing RNA was removed from the above precipitate. The RNA phase was washed in cool $80 \%$ ethanol and next, obtained RNA samples were stored in $80 \%$ ethanol at $-20^{\circ} \mathrm{C}$ for further analysis.

\section{Quantitative and qualitative analysis of RNA}

The RNA concentration and purity were measured by spectrophotometry on NanoDrop 2000 (Thermo Scientific, USA). Precipitate of RNA in $80 \%$ ethanol was taken out of $-20^{\circ} \mathrm{C}$ and next centrifuged for $15 \mathrm{~min}$ at $14,000 \mathrm{rpm}$ at $4^{\circ} \mathrm{C}$ in $5415 \mathrm{R}$ Eppendorf centrifuges. The liquid part was removed, and RNA pellets were left to dry completely at room temperature. Subsequently, the precipitate was dissolved in DNase-, RNase-, and protease-free water (Sigma-Aldrich, USA) at $4^{\circ} \mathrm{C}$, the volume depending on RNA concentration.

\section{The cDNA synthesis}

The cDNA was synthesized using High-Capacity cDNA Reverse Transcription Kit, according to manufacturer's instructions (Applied Biosystems, USA). Each reactive mixture contained the following set of reagents: $1 \times$ RT buffer, $20 \mathrm{U}$ RNase inhibitor, 50 $\mathrm{U}$ reverse transcriptase (Multiscribe Reverse Transcriptase), $1 \times$ RT Random Primers, $4 \mathrm{mM}$ of each deoxynucleotide: dATP, dGTP, dTTP, and dCTP plus 
examined $1 \mu \mathrm{g}$ RNA in DNase-, RNase-, and proteasefree water (Sigma-Aldrich, USA) to complete the volume required for reaction. Final volume of reactive mixture was $20 \mu \mathrm{l}$. Afterwards, the reactive components were thoroughly mixed and centrifuged to fuse them well. The cDNA was synthesized on Veriti Dx (Applied Biosystems, USA) under the following conditions: stage I: $25^{\circ} \mathrm{C}, 10 \mathrm{~min}$, stage II: $37^{\circ} \mathrm{C}, 120 \mathrm{~min}$, stage III: $85^{\circ} \mathrm{C}, 5 \mathrm{~min}$, stage IV: $4^{\circ} \mathrm{C}$.

\section{The qPCR protocol}

The cDNA, which was obtained by reverse transcription (RT) procedure, was amplified by real-time gene expression analysis (qPCR) on 7900HT Real-Time Fast System (Applied Biosystems, USA), using the manufacturer's SDS software. Triplicate qPCR reactions were conducted for each sample. To exclude reagent contamination by foreign DNA, a blind trial was always performed without DNA target. Reaction components included: $1.25 \mu \mathrm{l}$ mixture of probe and oligonucleotide starters specific for genes examined, $12.5 \mu \mathrm{lbuffer}$ TaqMan Universal PCR Master Mix, $1 \mu \mathrm{l}$ cDNA, DNase-, RNase-, and protease-free water (Sigma Aldrich, USA) to complete the required reactive volume. The reaction was performed on optic $25 \mu$ l-well reaction plate, using probe sets of TaqMan Gene Expression Assays (Applied Biosystems, USA) with FAM-NFQ markers and oligonucleotide starters for rat genes: App, Bace 1, Psen 1, Psen 2, and the housekeeping gene: Rpl13a was used as an internal control gene [36]. Amplification protocol included the following cycles: initial denaturation: $95^{\circ} \mathrm{C}, 10 \mathrm{~min}$, and 40 cycles each composed of two temperatures: $95^{\circ} \mathrm{C}, 15 \mathrm{~s}$, and $60^{\circ} \mathrm{C}$, $1 \mathrm{~min}$. The number of copies of DNA molecules was monitored and calculated on 7900HT Real-Time Fast System (Applied Biosystems, USA) in each amplification cycle. To calculate the number of examined DNA molecules present in the mixture at the onset of reaction, the number of PCR cycles after which the level of fluorescence exceeded the defined threshold cycle $\left(\mathrm{C}_{\mathrm{T}}\right)$ RQ Study Software (Applied Biosystems, USA) was used. The $C_{T}$ value for each sample of endogenous control gene (Rpl13a) was used to normalize the level of the interesting gene expression. The relative level of gene expression was calculated according to the formula [37]: 1. Calculating $\mathrm{C}_{\mathrm{T}}$ differences between the target gene and the reference gene are presented below: for the examined after ischemia of hippocampal CA1 area: $\Delta \mathrm{C}_{\mathrm{T} \text { ischemic sample }}=\mathrm{C}_{\mathrm{T}}$ target gene from ischemic

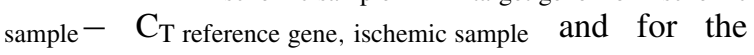

calibrator (control sample): $\Delta \mathrm{C}_{\mathrm{T} \text { calibrator }}=\mathrm{C}_{\mathrm{T} \text { target }}$ gene from control sample $-\mathrm{C}_{\mathrm{T}}$ reference gene, control sample. 2. Normalizing $\Delta \mathrm{C}_{\mathrm{T}}$ of the ischemic sample to the $\Delta \mathrm{C}_{\mathrm{T}}$ of the calibrator $\Delta \Delta \mathrm{C}_{\mathrm{T}}=\Delta \mathrm{C}_{\mathrm{T}}$ ischemic sample-

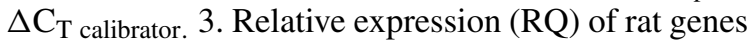
was calculated by the formula: $R Q=2^{-\Delta \Delta C}$. The RQ defines the expression of examined gene in the CA1 area of hippocampus taken from an ischemic rat with reference to the gene expression in the same structure of a control rat. Finally, the RQs were analyzed after their logarithmic conversion into logarithm of RQ (LogRQ) [38]. Thus, the obtained results were more legible. $\operatorname{LogRQ}=\mathrm{O}$ means that gene expression in the calibrated sample and the ischemic one are the same. $\operatorname{LogRQ}<0$ points to decreased gene expression in the ischemic sample, whereas $\operatorname{LogRQ}>0$ points to signal increased gene expression in the ischemic sample compared to the calibrated one.

\section{Statistical analysis}

The results were statistically analyzed by SPSS v. 17 software by means of the non-parametric MannWhitney U test and Spearman rho correlation analysis. Data were presented as means \pm SEM. The level of statistical significance was set at $p<0.05$.

\section{RESULTS}

Changes in gene expression of presenilin 1, presenilin 2, $\beta$-secretase, and $A \beta P P$ in rats two days after total cerebral ischemia

Presenilin 1 gene expression increased to a maximum of 2.203 - fold, presenilin 2 - to 3.208 - fold, $\beta$-secretase - to 3.916 - fold, and the expression of A $\beta P P$ gene decreased to a minimum -0.542 . The mean expression levels of genes were as follows: presenilin 1 $0.508 \pm 0.298$, presenilin $21.449 \pm 0.323$, $\beta$-secretase $2.642 \pm 0.414$, and $\mathrm{A} \beta \mathrm{PP}-0.075 \pm 0.101$ (Figs. 1-4).

\section{Changes in gene expression of presenilin 1,} presenilin 2, $\beta$-secretase, and A $\beta P P$ in rats 7 days after total cerebral ischemia

Presenilin 1 gene expression increased to a maximum of 0.874 , presenilin 2 - to $0.709, \beta$-secretase - to 0.952 , and the A $\beta P P$ gene - to 0.746. The mean expression levels of genes were the following: presenilin 1 $0.175 \pm 0.061$, presenilin $20.129 \pm 0.064$, $\beta$-secretase $0.121 \pm 0.113$, and AßPP $0.477 \pm 0.042$ (Figs. 1-4). 


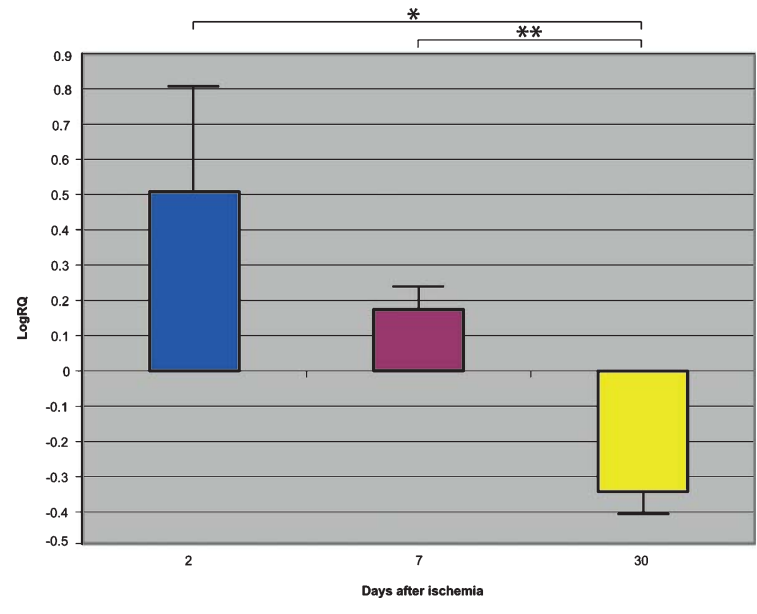

Fig. 1. The mean gene expression levels of presenilin 1 in the hippocampus CA1 area in rats 2, 7, and 30 days after 10-min of global brain ischemia. Marked SEM, standard error of the mean. Indicated statistically significant differences in levels of gene expression between 2 and 30 and between 7 and 30 days after 10-min of global brain ischemia (Mann-Whitney $\mathrm{U}$ test). ${ }^{*} p \leq 0.005,{ }^{* *} p \leq 0.0001$.

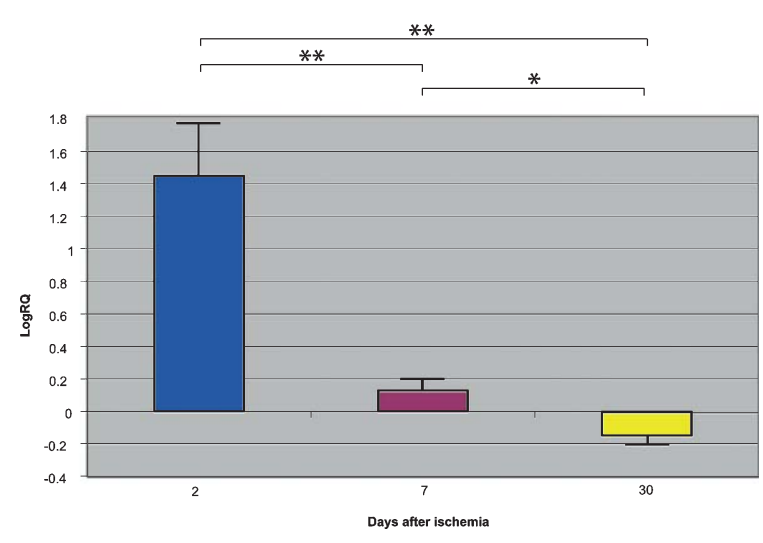

Fig. 2. The mean gene expression levels of presenilin 2 in the hippocampus CA1 area in rats 2, 7, and 30 days after 10-min of global brain ischemia. Marked SEM, standard error of the mean. Indicated statistically significant differences in levels of gene expression between 2 and 30 and between 2 and 7 and between 7 and 30 days after 10-min of global brain ischemia (Mann-Whitney $\mathrm{U}$ test). ${ }^{*} p \leq 0.005,{ }^{* *} p \leq 0.0001$.

Changes in gene expression of presenilin 1, presenilin 2, $\beta$-secretase, and $A \beta P P$ in rats 30 days after total cerebral ischemia

Presenilin 1 gene expression decreased to a minimum of -1.093 , presenilin 2 - to $-0.728, \beta$-secretase - to -0.731 , and the A $\beta P P$ gene expression increased to 0.623 . The mean expression levels of genes were as follows: presenilin $1-0.343 \pm 0.059$, presenilin

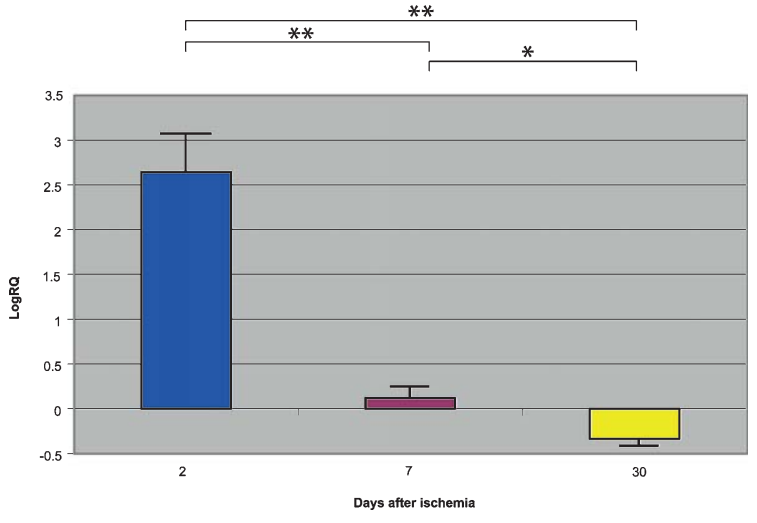

Fig. 3. The mean gene expression levels of $\beta$-secretase in the hippocampus CA1 area in rats 2, 7, and 30 days after 10-min of global brain ischemia. Marked SEM, standard error of the mean. Indicated statistically significant differences in levels of gene expression between 2 and 30 and between 2 and 7 and between 7 and 30 days after 10-min of global brain ischemia (Mann-Whitney U test). ${ }^{*} p \leq 0.002,{ }^{* *} p \leq 0.0001$.

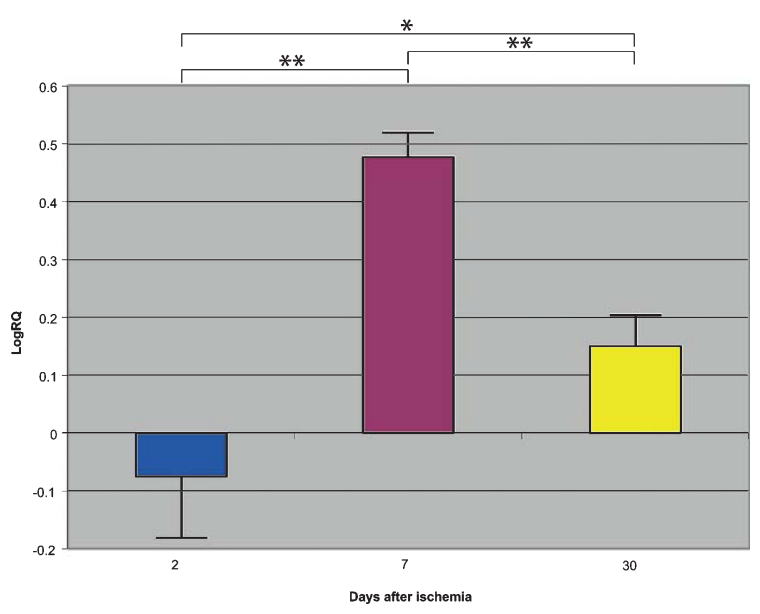

Fig. 4. The mean gene expression levels of amyloid- $\beta$ protein precursor in the hippocampus CA1 area in rats 2, 7, and 30 days after 10-min of global brain ischemia. Marked SEM, standard error of the mean. Indicated statistically significant differences in levels of gene expression between 2 and 30 and between 2 and 7 and between 7 and 30 days after 10-min of global brain ischemia (Mann-Whitney $\mathrm{U}$ test). ${ }^{*} p \leq 0.05,{ }^{* *} p \leq 0.0001$.

$2-0.131 \pm 0.052, \beta$-secretase $-0.335 \pm 0.064$, and А $\beta$ PP $0.151 \pm 0.051$ (Figs. 1-4).

Summary of the mean levels of gene expression in hippocampal CAl area in rats after 2, 7, and 30 days following the resumption of circulation after total brain ischemia

Figures 1-4 show changes in the mean expression levels of genes with statistical significance: presenilin 
1 (Fig. 1), presenilin 2 (Fig. 2), $\beta$-secretase (Fig. 3), and the A $\beta P P$ (Fig. 4) after 10-min total cerebral ischemia in rats with survival of 2,7 , and 30 days. Significant correlations between the expression of genes in the rat hippocampal CA1 area 2, 7, and 30 days after global brain ischemia was evident for Psen 1 and Psen 2, Psen 1 and Bace 1, and Psen 2 and Bace 1 (Spearman rho correlation test $p \leq 0.01)$.

\section{DISCUSSION}

In this paper, we studied alterations in the expression of A $\beta P P, \beta$-secretase, presenilin 1, and 2 Alzheimerrelated genes in rats subjected to a brief (10-min) complete brain ischemia. For the first time, we show here the time course of A $\beta P P, \beta$-secretase, and presenilin 1 and 2 genes dysregulation in the CA1 sector of hippocampus following complete brain ischemia. Our data provide the first known in vivo role of the dysregulation of Alzheimer-related genes in neuronal death postischemia. Additionally, our data demonstrate that brain ischemia activates delayed neuronal death in hippocampus in an A $\beta P P$-dependent manner, thus defining a new and important mode of regulation of ischemic cell death.

Following complete brain ischemia, some areas of the brain become more susceptible to neuronal damage/death than others, a phenomenon known as selective delayed neuronal death and/or selective vulnerability [13-16, 39]. The nature of molecular events involved in selective vulnerability of CA1 subfield of hippocampus has been disappointingly limited. To the best of our knowledge, data presented by us constitute the first report of its kind linking ischemia with acute, quantitative expression selected Alzheimerrelated genes (A $\beta P P, \beta$ - and $\gamma$-secretase). These data might support the hypothesis that the $A \beta$ peptide generated by ischemia could be involved in the ischemia-related AD [20, 24, 40-49].

In the present study, we have demonstrated that 2 days of recirculation postischemia resulted in a quick and huge overexpression of A $\beta P P$ protease genes such as $\beta$-secretase and $\gamma$-secretase (presenilin 1 or presenilin 2) associated with $A \beta$ peptide generation and development of $\mathrm{AD}$. The investigated genes were impressively changed at 2 days postischemia; a maximum expression of $\beta$-secretase gene increased 3.916-fold, that of presenilin 1-2.203-fold, and that of presenilin 2-3.208-fold. Interestingly, at that time we observed downregulation in A $\beta P P$ gene expression in the hippocampal CA1 area postischemia (a minimum of -0.542 -fold). This may be associated with the onset of necrotic neurodegenerative processes of pyramidal neurons in the hippocampal CA1 subfield [33, 50]. The level of expression of A $\beta P P$ investigated gene did not coincide with the earlier data concerning staining of different parts of A $\beta P P$ [17]. Our results show that there is a discrepancy between both A $\beta P P$ and secretase gene expression in the ischemic hippocampal CA1 region at 2 days postischemia. Currently, it has become clear that at this time necrotic neuronal cell death is associated with ischemia-reperfusion hippocampal CA1 area neurodegeneration [51-60]. Now, it has become obvious that at this time necrotic neuronal brain pathology is associated with the abnormal deposition of A $\beta P P$ [33]. In the hippocampus, granular deposits of A $\beta P P$ immunolabeling appear in the damaged CA1 area [33]. Lysosomal leakage appears at days 2 and 3 postischemia in hippocampal CA1 area neurons [53] which are a homogenous neuronal population [60]. Morphology-based studies have found that the vast majority of ischemic CA1 neurons display necrosis-like features and only a minority show morphologic changes similar to apoptosis [60]. During necrotic neuronal death, increased cytoplasm $\mathrm{Ca}^{2+}$ concentration [61] leads to mitochondrial dysfunction, activation of phospholipases, and proteases initiate lipid and DNA damage, and finally, the loss of membranes' integrity/plasma membrane rupture $[52,54,57$, $62]$. A $\beta P P$ is present in large quantities in all cell membranes [63] and in the above mentioned situation, there is an excess of secretase substrate which is the AßPP. The loss of membrane integrity and release of intracellular content, grant necrotic cells the ability to induce a pathological A $\beta P P$ metabolism in a vicious cycle $[58$, 63]. This assumption is apparently supported by A $\beta P P$ immunolabeling the remnants of necrotic CA1 neurons [33].

Our data indicate that in the 7 consecutive days, the $\beta$-secretase (maximal increase of 0.952 -fold), presenilin 1 and 2 gene (maximal increase of 0.874- and 0.709 -fold, respectively) expression dropped subsequently, but it was still above the control values. At that time, overexpression of A $\beta P P$ gene was noted (maximal 0.746-fold). The data demonstrate an increase in A $\beta P P$ gene expression in the selectively vulnerable CA1 sector of hippocampus after 10-min complete brain ischemia at the 7 th day postischemia. These results are complementary to the increase noted in different parts of A $\beta P P$ immunostaining after 7 days of recirculation [17]. But after 30 days, gene expression of secretases was below the control level (maximal $\beta$-secretase -0.731 -fold, presenilin 1 -1.093-fold, and 
presenilin $2-0.728$-fold) and A $\beta P P$ was overexpressed (maximal 0.623-fold). During 30 days postischemia, there was almost complete loss of CA1 area neuronal population of hippocampus and, therefore, A $\beta P P$ gene expression was increased at that time. The expression of all studied genes at this time negatively correlates with intra- and extracellular immunostaining of gene products [17, 27, 28, 30, 31, 33]. Intra- and extracellular $\mathrm{A} \beta$ peptide immunoreactivity in hippocampal CA1 area increases for as long as a year after injury, indicating that $A \beta$ peptide accumulation may continue long after $\beta$-secretase and presenilin gene expression goes to below the control value $[30,64]$. Presumably, local and global disturbances in A $\beta P P$ processing can be distinguished. This phenomenon is probably related to movement of A $\beta P P / A \beta$ peptide from blood into brain tissue $[22,65]$. It was also shown that RAGE protein enhanced ischemic vessel wall permeability $[66,67]$.

The available evidence indicates that the selective vulnerability of neuronal cells to global brain ischemia is determined by both ischemic episode and reperfusion. At present, there are at least three factors considered to be important in irreversible damage of vulnerable sectors of ischemic brain during short-term survival, which are independent of both the duration of ischemia and recirculation. They include: glutamate neurotoxicity, intraneuronal loading of calcium, and tissue acidosis $[26,61]$. Ischemia-induced A $\beta P P$, $\beta$-secretase, and $\gamma$-secretase (presenilins) dysregulation may provide excess soluble form of $A \beta$ peptide, which in turn could act as an additional neurotoxin which disrupts neuronal function and increases cell death through multiple mechanisms, including additionally impaired calcium homeostasis, initiation of neuroinflammatory processes [58], loss of neurovascular integrity [66, 67], and reactivity with blood-brain barrier permeability [23, 26-30, 43, 68, 69]. Several lines of evidence suggest that production of $A \beta$ peptide reduces neuroplasticity and contributes to increased neuronal vulnerability to ischemia $[9,43,49,69$, 70]. On the other hand, overexpression of Alzheimerrelated genes during recirculation may constitute a self-sustaining vicious cycle that leads to progressive neurodegeneration beginning in hippocampus $[71,72]$. A pathological hallmark of $\mathrm{AD}$, the most prevalent neurodegenerative disease, is the accumulation of plaques formed by $\mathrm{A} \beta$ peptide, commencing in the hippocampus, and spreading progressively throughout the brain $[69,71,72]$. It is likely that the accumulation is caused by both increased production and impaired clearance of $A \beta$ peptide and/or movement of $A \beta$ peptide and other parts of A $\beta P P$ fromblood into CA1 area of hippocampus
$[22,65]$. It was also noted that RAGE may additionally contribute to delayed neuronal death in hippocampus by enhancing ischemic vascular wall injury $[66,67]$. These data corroborate earlier immunohistochemical observation from animal models of complete brain ischemia and from brains after cardiac arrest in humans, which all suggest a direct relationship between ischemia and increased amyloidogenic A $\beta P P$ processing $[17,18,32]$. These findings are consistent with previous studies in semiquantitative analysis of secretases in local brain ischemia models and further confirm the participation of $\beta$-secretase [73] and presenilin 1 and 2 in ischemiainduced $A \beta$ peptide generation $[74,75]$. Combined all together, upregulation of genes found in our study suggests that $\beta$-secretase, presenilin 1 and 2 activation persist for 2-7 days after ischemia in hippocampal CA1 area. These data indicate that, in ischemic pyramidal neurons, A $\beta P P, \beta$-secretase, and $\gamma$-secretase conspire to promote an additional pathological sequence resulting in cell death. $\beta$-secretase activation can then cause further apoptotic signaling inducing caspase activation and DNA fragmentation, both events being observed in $\mathrm{AD}$ brains [76]. These findings will make it possible to understand the gradual postischemic damage in the structure of brain cells, delayed $A \beta$ peptide deposition, and long-term ischemic pathogenesis of AD. The present data may partly help to define the molecular mechanism of higher occurrence of neuronal death in ischemic hippocampal CA1 area.

The induction of three A $\beta$ PP metabolism-related genes, $\beta$-secretase, presenilin 1 and 2 , was quick during $2-7$ days postischemia. In the following 30 days, the $\beta$-secretase, presenilin 1 and 2 gene expression was downregulated. The above changes are associated with the loss of hippocampal CA1 area neurons, hippocampal and brain atrophy [26], and finally result in Alzheimer-type dementia [7-9, 24, 62]. These findings suggest that both abnormal expression of Alzheimerrelated genes and accumulation of their products induced by ischemia/reperfusion might play a critical role in necrotic neurodegeneration of CA1 area pyramidal neurons [24, 30, 33, 47, 62]. This also suggests that the above processes may be directly associated with neuronal death in ischemia. Our study indicates that transcription processes positively correlate with the condition of ischemic neurons. The expression of investigated genes was decreased at late stages (30 days) after ischemia. This may be reflected by the decrease and finally complete disappearance of pyramidal neurons in CA1 area of the hippocampus.

According to our data and the findings reported by other authors, it can be summarized that focal and/or 
global ischemia and reperfusion dysregulate $\mathrm{A} \beta \mathrm{PP}$ at both gene and protein levels and lead to $A \beta$ peptide accumulation. Lessons learned from investigation of ischemic hippocampal CA1 area genes that contribute to neuronal death and $A \beta$ peptide generation will be important for the elaboration of therapeutic targets to treat Alzheimer-type dementia. Further studies on this topic are obviously needed. Finally, the rat model employed in the present study seems to be a useful experimental approach for delineation of the role of gene dysregulation in neurodegenerative disorders such as sporadic AD.

\section{ACKNOWLEDGMENTS}

The authors acknowledge support by the Polish National Science Centre (DEC-2013/09/B/NZ7/ 01345-RP) and by Medical University of Lublin (DS 475-SJC and 222/14-JK). The paper was developed using the equipment purchased within the Project "The equipment of innovative laboratories doing research on new medicines used in the therapy of civilization and neoplastic diseases" within the Operation Program Development of Eastern Poland 2007-2013, Priority Axis I Modern Economy, Operations I.3 Innovation Promotion (JK, SJC).

Authors' disclosures available online (http://j-alz. com/manuscript-disclosures/15-0299r2).

\section{REFERENCES}

[1] Lim C, Alexander MP, LaFleche G, Schnyer DM, Verfaellie M (2004) The neurological and cognitive seguelae of cardiac arrest. Neurology 63, 1774-1778.

[2] Van Alem AP, De Vos R, Schmand B, Koster RW (2004) Cognitive impairment in survivors of out-of-hospital cardiac arrest. Am Heart J 148, 416-421.

[3] Lundgren-Nilsson A, Rosen H, Hofgren C, Sunnerhagen KS (2005) The first year after successful cardiac resuscitation: Function, activity, participation and quality of life. Resuscitation 66, 285-289.

[4] Bartsch T, Alfke K, Stingele R, Rohr A, Freitag-Wolf S, Jansen O, Deuschl G (2006) Selective affection of hippocampal CA-1 neurons in patients with transient global amnesia without long-term sequelae. Brain 129, 2874-2884.

[5] Ishibashi S, Kuroiwa T, LiYuan S, Katsumata N, Li S, Endo S, Mizusawa H (2006) Long-term cognitive and neuropsychological symptoms after global cerebral ischemia in Mongolian gerbils. Acta Neurochir (Suppl) 96, 299-302.

[6] Schreckinger M, Geocadin RG, Savonenko A, Yamashita S, Melnikova T, Thakor NV, Hanley DF (2007) Long-lasting cognitive injury in rats with apparent full gross neurological recovery after short-term cardiac arrest. Resuscitation $\mathbf{7 5}$, 105-113.

[7] Barra de la Tremblaye P, Plamondon H (2011) Impaired conditioned emotional response and object recognition are concomitant to neuronal damage in the amygdale and perirhinal cortex in middle-aged ischemic rats. Behav Brain Res 219, 227-233.

[8] Kiryk A, Pluta R, Figiel I, Mikosz M, Ułamek M, Niewiadomska G, Jabłoński M, Kaczmarek L (2011) Transient brain ischemia due to cardiac arrest causes irreversible long-lasting cognitive injury. Behav Brain Res 219, 1-7.

[9] Pluta R, Jabłoński M, Czuczwar SJ (2012) Postischemic dementia with Alzheimer phenotype: Selectively vulnerable versus resistant areas of the brain and neurodegeneration versus $\beta$-amyloid peptide. Folia Neuropathol 50, 101-109.

[10] Bloom GS (2014) Amyloid- $\beta$ and tau: The trigger and bullet in Alzheimer disease pathogenesis. JAMA Neurol 71, 505-508.

[11] Spires-Jones TL, Hyman BT (2014) The intersection of amyloid beta and tau at synapses in Alzheimer's disease. Neuron 82, 756-771.

[12] Flynn RWV, MacWalter RSM, Doney ASF (2008) The cost of cerebral ischemia. Neuropharmacology 55, 250-256.

[13] Ito U, Spatz M, Walker J, Klatzo I (1975) Experimental cerebral ischemia in Mongolian gerbils. I. Light microscopic observations. Acta Neuropathol 32, 209-223.

[14] Kirino T, Tamura A, Sano K (1984) Delayed neuronal death in the rat hippocampus following transient forebrain ischemia. Acta Neuropathol 64, 139-147.

[15] Petito C, Feldman E, Pulsinelli W, Plum F (1987) Delayed hippocampal damage in humans following cardiorespiratory arrest. Neurology 37, 1281-1286.

[16] Pluta R (2000) The role of apolipoprotein E in the deposition of $\beta$-amyloid peptide during ischemia-reperfusion brain injury. A model of early Alzheimer's disease. Ann NY Acad Sci 903, 324-334.

[17] Pluta R, Kida E, Lossinsky AS, Golabek AA, Mossakowski MJ, Wisniewski HM (1994) Complete cerebral ischemia with short-term survival in rats induced by cardiac arrest. I. Extracellular accumulation of Alzheimer's $\beta$-amyloid protein precursor in the brain. Brain Res 649, 323-328.

[18] Qi J, Wu H, Yang Y, Wand D, Chen Y, Gu Y, Liu T (2007) Cerebral ischemia and Alzheimer's disease: The expression of amyloid- $\beta$ and apolipoprotein $\mathrm{E}$ in human hippocampus. $J$ Alzheimers Dis 12, 335-341.

[19] Wen Y, Yang SH, Liu R, Perez EJ, Brun-Ziukemagel AM, Koulen P, Simpkins JW (2007) Cdk5 is involved in NFT-like tauopathy induced by transient cerebral ischemia in female rats. Biochim Biophys Acta 1772, 473-483.

[20] Yang SH, Simpkins JW (2007) Ischemia-reperfusion promotes tau and beta-amyloid pathology and a progressive cognitive impairment. In Ischemia-Reperfusion Pathways in Alzheimer's Disease, Pluta R, ed. Nova Science Publishers, Inc. New York, pp. 113-138.

[21] Mörtberg E, Zetterberg H, Nordmark J, Blennow K, Catry C, Decraemer H, Vanmechelen E (2011) Plasma tau protein in comatose patients after cardiac arrest treated with therapeutic hypothermia. Acta Anaesthesiol Scand 55, 1113-1132.

[22] Zetterberg H, Mörtberg E, Song L, Chang L, Provuncher GK, Patel PP, Ferrell E, Fournier DR, Kan CW, Campbell TG, Meyer R, Rivnak AJ, Pink BA, Minnehan KA, Piech T, Rissin DM, Duffy DC, Rubertsson S, Wilson DH, Blennow K (2011) Hypoxia due to cardiac arrest induces a timedependent increase in serum amyloid $\beta$ levels in humans. PLoS One 6, e28263.

[23] Langdon KD, Granter-Button S, Corbett D (2008) Persistent behavioral impairments and neuroinflammation following global ischemia in the rat. Eur J Neurosci 28, 2310-2318.

[24] Pluta R, Jabłoński M, Ułamek-Kozioł M, Kocki J, Brzozowska J, Januszewski S, Furmaga-Jabłońska W, Bogucka-Kocka A, Maciejewski R, Czuczwar SJ (2013) 
Sporadic Alzheimer's disease begins as episodes of brain ischemia and ischemically dysregulated Alzheimer's disease genes. Mol Neurobiol 48, 500-515.

[25] Katsuta K, Umemura K, Ueyama N, Matsuoka N (2003) Pharmacological evidence for a correlation between hippocampal CA1 cell damage and hyperlocomotion following global cerebral ischemia in gerbils. Eur J Pharmacol 467, 103-109.

[26] Pluta R, Ułamek M, Jabłoński M (2009) Alzheimer's mechanisms in ischemic brain degeneration. Anat Rec 292, 1863-1881.

[27] Pluta R (2003) Blood-brain barrier dysfunction and amyloid precursor protein accumulation in microvascular compartment following ischemia-reperfusion brain injury with 1-year survival. Acta Neurochir Suppl 86, 117-122.

[28] Pluta R (2005) Pathological opening of the blood-brain barrier to horseradish peroxidase and amyloid precursor protein following ischemia reperfusion brain injury. Chemotherapy 51, 223-226.

[29] Pluta R, Ułamek M, Januszewski S (2006) Micro-blood-brain barrier openings and cytotoxic fragments of amyloid precursor protein accumulation in white matter after ischemic brain injury in long lived rats. Acta Neurochir Suppl 96, 267-271.

[30] Pluta R, Januszewski S, Jabłoński M, Ułamek M (2010) Factors in creepy delayed neuronal death in hippocampus following brain ischemia-reperfusion injury with long-term survival. Acta Neurochir Suppl 106, 37-41.

[31] Jabłoński M, Maciejewski R, Januszewski S, Ułamek M, Pluta $\mathrm{R}$ (2011) One year follow up in ischemic brain injury and the role of Alzheimer factors. PhysiolRes (Suppl 1) 60, S113-S119.

[32] Maślińska D, Laure-Kamionowska M, Taraszewska A, Deręgowski K, Maśliński S (2011) Immunodistribution of amyloid beta protein $(A \beta)$ and advanced glycation endproduct receptors (RAGE) in choroid plexus and ependyma of resuscitated patients. Folia Neuropathol 49, 295-300.

[33] Lin B, Schmidt-Kastner R, Busto R, Ginsberg MD (1999) Progressive parenchymal deposition of $\beta$-amyloid precursor protein in rat brain following global cerebral ischemia. Acta Neuropathol 97, 359-368.

[34] Pluta R, Lossinsky AS, Mossakowski MJ, Faso L, Wiśniewski HM (1991) Reassessment of new model of complete cerebral ischemia in rats. Method of induction of clinical death, pathophysiology and cerebrovascular pathology. Acta Neuropathol 83, $1-11$.

[35] Chomczynski P, Sacchi N (1987) Single-step method of RNA isolation by acid guanidinium thiocyanate-phenol-chloroform extraction. Anal Biochem 62, 156-159.

[36] Yao L, Chen X, Tian Y, Lu X, Zhang P, Shi Q, Zhang J, Liu Y (2012) Selection of housekeeping genes for normalization of RT-PCR in hypoxic neural stem cells of rat in vitro. Mol Biol Rep 39, 569-576.

[37] Livak KJ, Schmittgen TD (2001) Analysis of relative gene expression data using real-time quantitative PCR and the $2^{-\Delta \Delta \mathrm{C}_{\mathrm{T}}}$ method. Methods 25, 402-408.

[38] Applied Biosystems (2007) Relative quantitation using comparative CT: Getting started guide, https://www3.applied biosystems.com/cms/groups/mcb_support/documents/general documents/cms_042115.pdf

[39] Pluta R, Ułamek-Kozioł M, Januszewski S, Ściślewska M, Bogucka-Kocka A, Kocki J (2012b) Alzheimer's factors in postischemic dementia. Rom J Morphol Embryol 53, 461-466.

[40] Kalaria RN (2000) The role of cerebral ischemia in Alzheimer's disease. Neurobiol Aging 21, 321-330.

[41] De la Torre JC (2004) Is Alzheimer's disease a neurodegenerative or a vascular disorder? Data, dogma, and dialectics. Lancet Neurol 3, 184-190.
[42] Pluta R (2004) From brain ischemia-reperfusion injury to possible sporadic Alzheimer's disease. Curr Neurovasc Res 1, 441-453.

[43] Koistinaho M, Koistinaho J (2005) Interactions between Alzheimer's disease and cerebral ischemia - focus on inflammation. Brain Research Rev 48, 240-250.

[44] Pluta R (2007) Ischemia-Reperfusion Pathways in Alzheimer's Disease. Nova Science Publishers Inc., New York.

[45] Bell R, Zlokovic B (2009) Neurovascular mechanisms and blood-brain barrier disorders in Alzheimer's disease. Acta Neuropathol 118, 103-113.

[46] Pluta R, Ułamek M, Jabłoński M (2010) Consideration of the ischaemic basis and treatment of Alzheimer's disease. Folia Neuropathol 48, 11-26.

[47] Pluta R, Kocki J, Maciejewski R, Ułamek-Kozioł M, Jabłoński M, Bogucka-Kocka A, Czuczwar SJ (2012) Ischemia signaling to Alzheimer-related genes. Folia Neuropathol 50, 322-329.

[48] Zhang Q, Gao T, Luo Y, Chen X, Gao G, Gao X, Zhou Y, Dai J (2012) Transient focal cerebral ischemia/reperfusion induces early and chronic axonal changes in rats: Its importance for the risk of Alzheimer's disease. PLoS One 7, e33722.

[49] Heikkinen R, Malm T, Heikkilä J, Muona A, Tanila H, Koistinaho M, Koistinaho J (2014) Susceptibility to focal and global brain ischemia of Alzheimer mice displaying $\mathrm{A} \beta$ deposits: Effect of immunoglobulin. Aging Dis 5, 76-87.

[50] Lin B, Ginsberg MD, Busto R (1998) Hyperglycemic exacerbation of neuronal damage following forebrain ischemia: Microglial, astrocytic and endothelial alterations. Acta Neuropathol 96, 610-620.

[51] Yamashima T, Tonchev AB, Tsukada T, Saido TC, ImajohOhmi S, Momoi T, Kominami E (2003) Sustained calpain activation associated with lysosomal rupture executes necrosis of the postischemic CA1 neurons in primates. Hippocampus 13, 791-800.

[52] Golstein P, Kroemer G (2007) Cell death by necrosis: Towards a molecular definition. Trends Biochem Sci 32, 37-43.

[53] Hara K, Yasuhara T, Matsukawa N, Maki M, Masuda T, Yu G, Xu L, Tambrallo L, Rodriguez NA, Stern DM, Kawase T, Yamashima T, Buccafusco JJ, Hess DC, Borlongan CV (2007) Hippocampal CA1 cell loss in a non-human primate model of transient global ischemia: A pilot study. Brain Res Bull 74, 164-171.

[54] Vanlangenakker N, Vanden Berghe T, Krysko DV, Festjens N, Vandenabeele P (2008) Molecular mechanisms and pathophysiology of necrotic cell death. Curr Mol Med 8, 207-220.

[55] Kroemer G, Galluzzi L, Vandenabeele P, Abrams J, Alnemri ES, Baehrecke EH, Blagosklonny MV, El-Deiry WS, Golstein P, Green DR, Hengartner M, Knight RA, Kumar S, Lipton SA, Malorni W, Nunez G, Peter ME, Tschopp J, Yuan J, Piacentini M, Zhivotovsky B, Melino G (2009) Classification of cell death: Recommendations of the Nomenclature Committee on Cell Death 2009. Cell Death Differ 16, 3-11.

[56] Wang JY, Xia Q, Chu KT, Pan J, Sun LN, Zeng B, Zhu YJ, Wang Q, Wang K, Luo BY (2011) Severe global cerebral ischemia induced programmed necrosis of hippocampal CA1 neurons in rat is prevented by 3-methyladenine: A widely used inhibitor of autophagy. J Neuropathol Exp Neurol 70, 314-322.

[57] Galluzzi L, Vitale I, Abrams JM, Alnemri ES, Baehrecke EH, Blagosklonny MV, Dawson TM, Dawson VL, El-Deiry WS, Fulda S, Gottlieb E, Green DR, Hengartner MO, Kepp O, Knight RA, Kumar S, Lipton SA, Lu X, Madeo F, Malorni W, Mehlen P, Nuñez G, Peter ME, Piacentini M, Rubinsztein 
DC, Shi Y, Simon HU, Vandenabeele P, White E, Yuan J, Zhivotovsky B, Melino G, Kroemer G (2012) Molecular definitions of cell death subroutines: Recommendations of the Nomenclature Committee on Cell Death 2012. Cell Death Differ 19, 107-120.

[58] Kaczmarek A, Vandenabeele P, Krysko DV (2013) Necroptosis: The release of damage-associated molecular patterns and its physiological relevance. Immunity 38, 209-223.

[59] Jouan-Lanhouet S, Riquet F, Duprez L, Vanden Berghe T, Takahashi N, Vandenabeele P (2014) Necroptosis, in vivo detection in experimental disease models. Semin Cell Dev Biol 35, 2-13.

[60] Müller GJ, Hasseldam H, Rasmussen RS, Johansen FF (2014) Dexamethasone enhances necrosis-like neuronal death in ischemic rat hippocampus involving $\mu$-calpain activation. Exp Neurol 261, 711-719.

[61] Pluta R, Salińska E, Puka M, Stafiej A, Łazarewicz JW (1988) Early changes in extracellular amino acids and calcium concentrations in rabbit hippocampus following complete 15-min cerebral ischemia. Resuscitation 16, 193-210.

[62] Pluta R, Furmaga-Jabłońska W, Maciejewski R, UłamekKozioł M, Jabłoński M (2013) Brain ischemia activates $\beta$ and $\gamma$-secretase cleavage of amyloid precursor protein: Significance in sporadic Alzheimer's disease. Mol Neurobiol 47, 425-434.

[63] Groemer TW, Thiel CS, Holt M, Riedel D, Hua Y, Hüve J, Wilhelm BG, Klingauf J (2011) Amyloid precursor protein is trafficked and secreted via synaptic vesicles. PLoS One 6 , e18754

[64] Masel BE, DeWitt DS (2010) Traumatic brain injury: A disease process, not an event. J Neurotrauma 27, 1529-1540.

[65] Pluta R, Barcikowska M, Januszewski S, Misicka A, Lipkowski AW (1996) Evidence of blood-brain barrier permeability/leakage for circulating human Alzheimer's $\beta$ amyloid-(1-42)-peptide. NeuroReport 7, 1261-1265.

[66] Kamide T, Kitao Y, Takeichi T, Okada A, Mohri H, Schmidt AM, Kawano T, Munesue S, Yamamoto Y, Yamamoto H, Hamada J, Hori O (2012) RAGE mediates vascular injury and inflammation after global cerebral ischemia. Neurochem Int 60, 220-228.
[67] Weil ZM (2012) Ischemia-induced hyperglycemia: Consequences, neuroendocrine regulation, and a role for RAGE. Horm Behav 62, 280-285.

[68] Pluta R, Jolkkonen J, Cuzzocrea S, Pedata F, Cechetto D, Popa-Wagner A (2011) Cognitive impairment with vascular impairment and degeneration. Curr Neurovasc Res 8, 342350.

[69] Sekeljic V, Bataveljic D, Stamenkovic S, Ułamek M, Jabłoński M, Radenovic L, Pluta R, Andjus PR (2012) Cellular markers of neuroinflammation and neurogenesis after ischemic brain injury in the long-term survival rat model. Brain Struct Funct 217, 411-420.

[70] Koistinaho M, Kettunen MI, Goldsteins G, Keinanen R, Salminen A, Ort M, Bures J, Liu D, Kauppinen RA, Higgins LS, Koistinaho J (2002) $\beta$-amyloid precursor protein transgenic mice that harbor diffuse $A \beta$ deposits but do not form plaques show increased ischemic vulnerability: Role of inflammation. Proc Natl Acad Sci U S A 99, 1610-1615.

[71] Ballard C, Gauthier S, Corbett A, Brayne C, Aarsland D, Jones E (2011) Alzheimer's disease. Lancet 377, 1019-1031.

[72] Selkoe D, Mandelkow E, Holtzman D (2012) Deciphering Alzheimer disease. Cold Spring Harb Perspec Med 2, a011460.

[73] Wen Y, Onyewuchi O, Yang S, Liu R, Simpkins JW (2004) Increased beta-secretase activity and expression in rats following transient cerebral ischemia. Brain Res 1009, 1-8.

[74] Tanimukai H, Imaizumi K, Kudo T, Katayama T, Tsuda M, Takagi T, Tohyama M, Takeda M (1998) Alzheimerassociated presenilin-1 gene is induced in gerbil hippocampus after transient ischemia. Mol Brain Res 54, 212-218.

[75] Pennypacker KR, Hernandez H, Benkovic S, Morgan DG, Willing AE, Sanberg PR (1999) Induction of presenilins in the rat brain after middle cerebral arterial occlusion. Brain Res Bull 48, 539-543.

[76] Abrahamson EE, Ikonomovic MD, Ciallella JR, Hope CE, Paljug WR, Isanski BA, Flood DG, Clark RS, DeKosky ST (2006) Caspase inhibition therapy abolishes brain traumainduced increases in Abeta peptide: Implications for clinical outcome. Exp Neurol 197, 437-450. 